\title{
Research on the reform strategy of college student management
}

\author{
Cai Yu \\ Sichuan Vocational and Technical College
}

629000

\section{Key words: college; student management; reform strategy}

\begin{abstract}
Reform the management of college students, it will help to standardize the college teaching management system, build a harmonious campus culture, do good campus security work and promote the development of college education. This paper will give examples to have a brief analysis of the college students management reform strategy, and put forward personal views.
\end{abstract}

\section{Introduction}

Promote the innovation and reform of college students management, improve the quality of college teaching management, teachers should cooperate with the school to innovate campus culture, and give students management work to flexible culture. Pay attention to the campus security work, cultivate students' safety consciousness. Based on the goal of college teaching management, cultivate high-quality talents.

\section{Innovating the campus culture, giving students management work with flexible culture}

The influence of culture on people is particularly important. Excellent campus culture can enrich the spiritual world of teachers and students, enhance the spiritual motivation of teachers and students, and improve the cultural accomplishment of all teachers and students. Therefore, the school can create a harmonious campus culture by strengthening the construction of campus culture, carrying out a variety of elegant and lively campus cultural activities. At present, the Ministry of National Education advocates the integration of traditional culture education and virtue education in the college students management, and comprehensively guides the whole school to learn the advanced culture of the Communist Party of China [ ${ }^{1]}$. In view of this idea, teachers can organize students to jointly organize " teacher - student talent competition "," traditional Chinese painting exhibition ", " calligraphy gallery "," ancient poetry reading ", " campus concert "," Chinese family precepts ", " Disciple Gauge "," Three Character Classic ", " campus sports meet"," reading month " and other kinds of excellent cultural activities to promote the balanced development of students in the cultural and moral aspects. On the occasion of " campus reading month ", teachers can guide students to read all kinds of excellent works, enrich students' cultural quality and purify students' moral emotion. In the process of literacy teaching and calligraphy teaching, teachers can integrate " Chinese character culture" into them, guiding students to understand Oracle, plain text, cursive script, seal script, official script, regular script and running script, etc., to tell students that Chinese characters is the essence of Chinese culture and is the most important carrier of Chinese culture, every Chinese character contains a wealth of cultural information, to a certain extent, understanding the Chinese characters will understand the Chinese culture. Because the ancients created the Chinese characters, gave each word very image creation, so behind every Chinese character there is the truth of its composition. When carrying out poetry teaching activities, teachers can design " poetry painting the spring "," learn to take advantage of the time " and" poetry to sing songs, " and so on, for students to read" the spring of poetry ", for example, after students reading " spring night rain ", pointing students realize:" spring night rain " use of anthropomorphic techniques, with great joy and meticulous description of the characteristics of the spring rain and the Chengdu rain at night, enthusiastically praise the spring rain that come in time and oisturize of all things. The description of spring rain in the poem, the body material subtle, delicate and vivid, like a picture. The full poem artistic conception is elegant, the implication is beautiful, the poem realm and the picturesque scene 
is integrated one, is a vivid and have unique charm praise rain poem. This can not only strengthen the students' classical cultural attainment, but also help to inherit the excellent traditional culture, enrich the essence and connotation of campus culture.

\section{Pay attention to the campus security work, cultivate students' safety consciousness}

The basic goal of campus security work is to ensure the safety of life and property of students and faculty members by carrying out a series of security measures, to promote the orderly progress of campus education work, to build a civilized and harmonious campus. The current campus security work mainly involves six aspects including campus security management, traffic safety management, fire safety management, students' mental health safety management, campus surrounding environment security management, property safety management ${ }^{[2]}$. Among them, the campus security management is reflected in two levels, the first level is to prohibit off-campus staff to enter the campus to endanger the campus safety, the second level is to prohibit students to cause safety accidents; Traffic safety management not only to avoid the off-campus vehicles to enter the campus arbitrarily, to do well in campus vehicle management, and to maintain the campus surrounding environment traffic safety; Fire safety management is mainly to prohibit students private connect wire, illegal use of electricity ( such as the use of water heater, rice cooker and induction cooker in the dormitory ), to do good campus chemical supplies management to prevent the occurrence of fire; Students' mental health safety management is to avoid the students because of psychological factors to commit suicide or hurt others events, need to help students adjust their attitude in time, out of the confused mind; The campus surrounding environment security management refers to the school should strengthen the connection with the nearby hotel, individual rental house, internet bar and KTV, and do the security work well; Property safety management should not only prevent students' property from being stolen, but also teach students to manage their own cash, bank cards and valuables ( like mobile phones, computers ). In the information age today, telecommunications fraud is increasingly rampant, criminals will through various channels to cheat students money, schools should teach students to beware of being cheated. We should do six security work to safeguard the security of the campus, build a civilized, safe and harmonious campus, purify the students' thoughts and create a safe and happy environment for students. When a safety accident occurs, the school should do a good job in dealing with it, impose the necessary safety management education, improve the students' self - protection ability. For example, when the student's property is stolen or cheated, the school should try its best to help the students recover the lost property, try to reduce the loss of the students, and take this as an example to teach students to manage good personal property, beware of fraud.

Secondly, colleges must work out a detailed and complete work system for campus security work, improve the work quality of the campus security personnel, guide staff to take turns on duty within 24 hours, and schools should encourage students to actively participate in campus security activities, build high-quality campus security team, strengthen campus network security management, prevent hackers from attacking the campus network, clear unhealthy information and dirty video, guide students to learn network laws and regulations, resist vulgar network culture and bad temptation, build a civilized, healthy and pure campus network for students.

In addition, colleges should pay attention to the safety and security awareness of students, to teach students to pay attention to traffic safety, not to participate in gambling activities, boycott drugs, access to off-campus hotels, bars, internet cafes, KTV and individuals must improve vigilance, protect the safety of life and property, and respect students' personal opinion and subjective status, guide students to find and be good at discovering the surrounding security problems, explore solutions to solve security problems, and do a summary of security work. Teachers can also actively integrate safety management education while carrying out cultural education activities, such as the integration of fire safety management knowledge in the interpretation of physical and electrical, and teach students not to use illegal electrical appliances. Moreover, teachers should cooperate with the school to play the role of collective education, contact the police team, public security bureau, fire brigade and other institutions around the campus, 
regularly invite the traffic police, police officers and firefighters to school to do security education lectures for students, strengthen the students' sense of security ${ }^{[3]}$.

\section{Utilize the goal of college teaching management, cultivate high-quality talents.}

To improve the quality of college student management, teachers should take " cultivate high quality talents" as the teaching goal, promote the all-round development of students in the fields of moral, intellectual, physical, art and labour, and give students the virtue education, intellectual development, physical training, aesthetic cultivation and the shaping of labor consciousness. When carrying out virtue education, we should fully integrate the Chinese traditional virtues, guide students to learn tolerance, honesty, unity, patriotism, modesty, diligence, perseverance ${ }^{[4]}$. When carrying out the intelligence education, teachers should pay attention to observe the students' interest, develop the students' talents, inspire the students' minds and guide students in their efforts to learn various scientific and cultural knowledge. When carrying out physical training, teachers can combine students' physique, interests and sports talents, cultivate students' sports spirit and strengthen students' sports skills. When carrying out aesthetic education, teachers should integrate aesthetic accomplishment into all disciplines, cultivate students' elegant and pure aesthetic taste, and develop students' talents to create beauty. In shaping the students' labor consciousness, teachers can combine the concept of " work and rest ", guide students to read Lao She's" the most taste of labor ", let the students experience the joy of labor.

\section{Concluding remarks}

In summary, to do well the reform of college students management work, to innovate the college teaching management mode, the school should organize all teachers and students to create a good campus culture, and give students management work to flexible culture. Pay attention to the campus security work, cultivate students' safety consciousness. Based on the goal of college teaching management, cultivate high-quality talents.

\section{Reference:}

[1] Li Yachun. Phonetics. The interactive integration of school - based teaching management and administrative teaching management $[\mathrm{j}]$. Teaching theory and practice, $2010(12: 1)$

[2] Wang Rengang, Wu Xuefeng. Discussion on the countermeasures of security work in higher vocational colleges [j ]. Journal of Huainan institute of technology, 2013, ( 06: 2 )

[3] Yang Jun. Discussion on the security work in the construction of harmonious culture in higher vocational colleges [ j ]. Contemporary education practice and teaching research, 2016 ( 03: 3 )

[4] Liu Junhua. The feasibility analysis and method research on the innovation of students management in higher vocational colleges [ j ]. Education for Chinese After-school, 2015 ( 22: 4 ) 